\title{
Effect of hot season on blood parameters, fecal fermentative parameters, and occurrence of Clostridium tyrobutyricum spores in feces of lactating dairy cows
}

\author{
L. Calamari, ${ }^{*}$ P. Morera,† P. Bani, ${ }^{*}$ A. Minuti, ${ }^{* 1}$ L. Basiricò,† A. Vitali, ł and U. Bernabucci† \\ *Istituto di Zootecnica, Università Cattolica del Sacro Cuore, Via Emilia Parmense, 84, 29122 Piacenza, Italy \\ †Dipartimento di Scienze Agrarie e Forestali (DAFNE), Università degli Studi della Tuscia, via S. Camillo De Lellis, s.n.c, 01100 Viterbo, Italy \\ łFacoltà di Bioscienze e Tecnologie Agroalimentari ed Ambientali, Università di Teramo, Via R. Balzarini 1, 64100 Teramo, Italy
}

\begin{abstract}
High temperature influences rumen and gut health, passage rate, and diet digestibility, with effects on fermentative processes. The main aim of the study was to investigate the effect of hot season on hindgut fermentation, the occurrence of Clostridium tyrobutyricum spores in bovine feces, and on their relationship with metabolic conditions in dairy cows producing milk used for Grana Padano cheese. The study was carried out on 7 dairy farms located in the Po Valley (Italy), involving 1,950 Italian Friesian dairy cows. The study was carried out from November 2013 till the end of July 2014. Temperature and relative humidity were recorded daily by weather stations. Constant management conditions were maintained during the experimental period. Feed and diet characteristics, metabolic conditions, and fecal characteristics were recorded in winter (from late November 2013 to the end of January 2014), spring (from April to May 2014), and summer (July 2014) season. In each season, blood samples were collected from 14 multiparous lactating dairy cows per herd to measure biochemical indices related to energy, protein, and mineral metabolism, as well as markers of inflammation and some enzyme activities. Fecal samples were also collected and measurements of moisture, $\mathrm{pH}$ and volatile fatty acids (VFA) were performed. The DNA extracted and purified from fecal samples was used to detect Clostridium tyrobutyricum spores in a quantitative real-time PCR assay. The daily mean temperaturehumidity index was $40.7 \pm 4.6$ (range 25 to 55 ), 61.2 \pm 3.7 (range 39 to 77 ), and $70.8 \pm 3.2$ (range 54 to 83 ) in winter, spring, and summer, respectively. Total VFA concentration in feces progressively decreased from winter to summer. The seasonal changes of acetate and propionate followed the same trend of total VFA;
\end{abstract}

Received August 16, 2017.

Accepted January 2, 2018.

${ }^{1}$ Corresponding author: andrea.minuti@unicatt.it conversely, butyrate did not show any difference between seasons, and its molar proportion was greater in summer compared with winter. A greater occurrence of Cl. tyrobutyricum spores in summer compared with the other seasons was observed. The plasma concentrations of glucose, urea, albumin, $\mathrm{Ca}, \mathrm{Mg}, \mathrm{Cl}, \mathrm{Zn}$, and alkaline phosphatase activity were lower in summer compared with winter, whereas the opposite occurred for bilirubin and Na. Our results show that summer season, through direct and indirect effect of heat stress, affected fecal fermentative parameters and hindgut buffering capacity, and was responsible for the increasing occurrence of Cl. tyrobutyricum spores in feces.

Key words: heat stress, dairy cows, Clostridium tyrobutyricum, metabolic conditions

\section{INTRODUCTION}

Climate change is likely to be one of the main challenges of the current century. In many regions of Italy, the summer period is characterized by climatic conditions that can adversely affect the welfare of farm animals and in particular of the dairy cows. It is known that dairy cow, because it generates a lot of metabolic heat, is sensitive to high environmental temperatures to which it reacts by implementing various physiological responses. These involve reduction of feed intake, reduction of growth rate (Nardone et al., 2010; Das et al., 2016), alteration of gastrointestinal function (Bernabucci et al., 1999, 2009; Kadzere et al., 2002), reduction of reproductive performances (Hansen, 2009), changes in the endocrine-metabolic system (Abeni et al., 2007; Bernabucci et al., 2010; Baumgard and Rhoads, 2013), impairment of immune system (Lacetera et al., 2005), and even animal death in extreme cases (Vitali et al., 2015). Many studies reported that high air temperatures, coupled with high relative humidity, negatively affect milk yield and its composition and cheesemaking properties (Bernabucci et al., 2014, 2015; Bertocchi et al., 2014). 
Among these latter ones, the microbiological properties play an important role to determine physical, chemical, and biological processes of cheesemaking and ripening. Many of the defects of long-ripening cheese obtained with raw milk are related to microbial contamination (Dasgupta and Hull, 1989; Garde et al., 2011). Late blowing, caused by butyric acid fermentation, is one of the most feared defects of longripened hard and semi-hard cheeses. In particular, Clostridium tyrobutyricum, an anaerobe gram-positive and endospore-forming bacterium, was identified as the main spoiling agent responsible for this defect in cheese (Le Bourhis et al., 2005; Lopez-Enriquez et al., 2007; Doyle et al., 2015), and its occurrence in milk is closely related to the contamination of raw milk during the milking process, before cheese production.

Clostridium ssp. spores are highly resistant to environmental conditions and are abundant mainly in feces and in dust, colonize skin and hair of animals, and can easily contaminate raw milk at milking time (Barash et al., 2010; Ledenbach and Marshall, 2010). The concentration of spores in feces, and consequently the contamination of the environment, is strictly related to the content of spores in feeds (silage in particular). Also, diets different in forage/concentrate ratio and starch content, modifying the fermentative processes in the digestive tract, may influence the excreted/ingested spore ratio (Bani et al., 2001). A relationship was observed between excreted/ingested spore ratio and the pH measured in feces (Bani et al., 2001). Therefore, the climate change could affect digestive activity and Clostridia contamination in milk. The hot conditions influence rumen and intestine health, passage rate, and diet digestibility (Bernabucci et al., 2009), with effects on fermentative processes and potential changes of factors influencing germination of Clostridia spores in the gut.

Only few studies are available on the effect of season on hindgut fermentation, also considering that animal feeding often varies depending on season and climate. Therefore, the aim of the present study was to investigate the effect of hot season on fecal fermentative parameters and on the occurrence of $\mathrm{Cl}$. tyrobutyricum spores in bovine feces and their relationship with metabolic conditions in dairy cows producing milk used for Grana Padano cheese.

\section{MATERIALS AND METHODS}

\section{Animals and Management}

The research and the animal care protocols were in accordance with the Directive 2010/63/EU of the European Parliament and of the Council of September 22,
2010, on the protection of animals used for scientific purposes (European Union, 2010).

The study was carried out on 7 dairy farms located in the Po Valley (Mantova and Brescia provinces). Only 7 farms were selected based of budgetary limitations and study complexity, using a convenience sample. The milk yielded by all herds was used to produce Grana Padano cheese. The herds were selected because they were representative of Grana Padano production area in terms of production system adopted (intensive), average milk yield per cow, and barn design and management (total confinement free barn housing with no time at pasture, TMR, and feeding practices based on corn silage). The herd size was $110,330,600,320,210$, 150, and 230 lactating and dry cows (herds A, B, C, $\mathrm{D}, \mathrm{E}, \mathrm{F}$, and $\mathrm{G}$, respectively). All herds were freestall barns equipped with axial flow fans and sprinklers in the feeding area. Lactating cows were fed TMR once a day, in the morning. To ensure cows had ad libitum access to the TMR, the amount offered to the cows was assessed on a daily basis with the aim of producing a 3 to $8 \%$ refusal. Cows were milked twice daily (0300-0500 $\mathrm{h}$, and $1500-1700 \mathrm{~h}$ ).

Constant management conditions within farm (operators, similar batches of feed, milking frequency, and working routine) were maintained thorough the experimental period.

The study was carried out from November 2013 until the end of July 2014. Measurements on microclimatic conditions, feed and diets, metabolic conditions, and fecal characteristics were carried out in winter (from the end of November 2013 to the end of January 2014), spring (from April to May 2014), and summer (July 2014). Individual blood and fecal samples were taken in each season from 14 cows per farm. The cows were selected according to parity and lactation stage [7 cows in early lactation: 30-90 d in milk (DIM), and 7 cows in mid lactation: 160-240 DIM]. The parity number and DIM, as well as milk yield of the selected cows are showed in Table 1. The sampling days in winter season were distributed in a wider period of time because climate conditions are quite stable, in spring the sampling days were mainly concentrated in May (5 farms), and finally in summer they were concentrated during the hottest period (July).

\section{Measurements and Analyses}

Microclimatic Conditions. The weather stations providing the climatic data belonged to the following institutions: Regional Environmental Protection Agency of the Lombardy Region and the Research Unit for Agricultural Climatology and Meteorology. The distances between farms and weather stations were calculated 
and each farm was associated with the nearest weather station, located within a minimum radius of $0.3 \mathrm{~km}$ and maximum radius of $30 \mathrm{~km}$, with an average distance of $10.9 \pm 6.0 \mathrm{~km}$. Supplemental Figure S1 (https:// doi.org/10.3168/jds.2017-13693; ESRI, 2015) shows a map of the studied area where the weather stations and dairy farms are located.

Data were used to compute a composite climatic welfare index, the temperature-humidity index (THI), according to the formula of Kelly and Bond, as reported by Ingraham et al. (1979):

$$
\begin{aligned}
\mathrm{THI} & =(1.8 \cdot \mathrm{AT}+32)-(0.55-0.55 \cdot \mathrm{RH}) \\
& \cdot[(1.8 \cdot \mathrm{AT}+32)-58],
\end{aligned}
$$

where AT is the ambient temperature expressed as ${ }^{\circ} \mathrm{C}$, and $\mathrm{RH}$ is the relative humidity expressed as fraction of the unit.

Mean, minimum, and maximum daily THI were also calculated throughout the study.

Feeds and Diets. Representative samples of forages, concentrate mixtures, and TMR were collected at each sampling day before blood and fecal collection. Feeds samples were analyzed for moisture, CP, crude fiber, starch, and ash (AOAC, 1990); aNDFom was analyzed with a heat-stable amylase with correction for residual ash, according to the method of Mertens (1997), and using an Ankom 2200 (Macedon, NY) for extraction and filtering. The chemical and nutritive characteristics of the diets were calculated at each sampling day according to NRC (2001).
Blood Sampling and Analysis. Blood samples from the jugular vein were collected in 10-mL Li-heparin tubes (Vacuette, containing 18 IU of Li-heparin/ mL, Kremsmünster, Austria) before TMR distribution and immediately cooled in ice water.

A small amount of blood was used for packed cell volume $(\mathbf{P C V})$ determination in a capillary tube after high-speed centrifugation $(15,000 \times g$ for $10 \mathrm{~min}$ at room temperature). The remaining blood was centrifuged $\left(3,500 \times g\right.$ for $16 \mathrm{~min}$ at $\left.4^{\circ} \mathrm{C}\right)$ and the plasma was separated into several aliquots and stored at $-20^{\circ} \mathrm{C}$ until further analyses. Plasma metabolites were analyzed at $37^{\circ} \mathrm{C}$ by an automated clinical analyzer (ILAB 600 , Instrumentation Laboratory, Lexington, MA). Commercial kits were used to measure glucose, total cholesterol, urea, calcium, inorganic phosphorus, magnesium, total protein, albumin, total bilirubin (Instrumentation Laboratory, Lexington, MA), and zinc (Wako, Chemicals GmbH, Neuss, Germany). Kinetic analysis was used to determine activity of alkaline phosphatase (AP; EC 3.1.3.1), aspartate aminotransferase (EC 2.6.1.1), and $\gamma$-glutamyl transferase (EC 2.3.2.2) using commercial kits (Instrumentation Laboratory, Lexington, MA). Ceruloplasmin and haptoglobin were determined according to the methods reported by Calamari et al. (2016).

Fecal Sampling and Analysis. After blood collection, a fecal sample was collected from the rectal ampulla. The samples were delivered to the laboratory immediately after collection. The moisture content (in a ventilated oven at $65^{\circ} \mathrm{C}$ ) and the $\mathrm{pH}$ (potentiometric method) were measured for each sample. For VFA analysis, $10 \mathrm{~g}$ of fecal sample was added to $90 \mathrm{~mL}$ of

\begin{tabular}{|c|c|c|c|c|c|c|c|}
\hline \multirow[b]{2}{*}{ Farm } & & \multicolumn{2}{|c|}{ Winter } & \multicolumn{2}{|c|}{ Spring } & \multicolumn{2}{|c|}{ Summer } \\
\hline & & Mean & $\mathrm{SD}$ & Mean & $\mathrm{SD}$ & Mean & $\mathrm{SD}$ \\
\hline \multirow[t]{3}{*}{ A } & PN & 3.29 & 2.30 & 3.54 & 1.71 & 3.30 & 1.60 \\
\hline & DIM & 155.79 & 73.60 & 120.46 & 72.85 & 130.64 & 79.06 \\
\hline & MY (kg/d) & 36.47 & 9.74 & 42.55 & 7.37 & 36.86 & 7.04 \\
\hline \multirow[t]{3}{*}{ B } & PN & 2.38 & 0.51 & 2.60 & 0.83 & 2.29 & 0.61 \\
\hline & DIM & 137.42 & 74.68 & 151.87 & 71.50 & 127.64 & 72.94 \\
\hline & MY (kg/d) & 44.68 & 5.19 & 41.14 & 8.78 & 41.86 & 11.37 \\
\hline \multirow[t]{3}{*}{$\mathrm{C}$} & $\mathrm{PN}$ & 1.86 & 0.95 & 2.93 & 0.92 & 2.55 & 0.82 \\
\hline & DIM & 150.64 & 63.59 & 134.57 & 76.48 & 131.00 & 68.64 \\
\hline & MY (kg/d) & 41.78 & 5.61 & 34.30 & 8.00 & 35.73 & 12.79 \\
\hline \multirow[t]{3}{*}{ D } & $\mathrm{PN}$ & 3.14 & 1.03 & 2.92 & 1.04 & 3.29 & 0.99 \\
\hline & DIM & 129.14 & 79.70 & 133.92 & 74.70 & 102.62 & 61.30 \\
\hline & MY (kg/d) & 41.78 & 10.49 & 39.42 & 9.11 & 41.40 & 5.03 \\
\hline \multirow[t]{3}{*}{$\mathrm{E}$} & $\mathrm{PN}$ & 2.80 & 0.70 & 2.50 & 0.80 & 2.64 & 0.93 \\
\hline & DIM & 133.00 & 68.00 & 125.00 & 60.00 & 131.29 & 63.68 \\
\hline & MY (kg/d) & 36.70 & 7.92 & 39.32 & 8.21 & 34.87 & 6.81 \\
\hline \multirow[t]{3}{*}{$\mathrm{F}$} & PN & 2.23 & 0.60 & 3.25 & 1.29 & 2.79 & 0.80 \\
\hline & DIM & 119.92 & 69.99 & 122.31 & 69.00 & 190.36 & 76.32 \\
\hline & MY (kg/d) & 43.15 & 10.74 & 45.68 & 9.19 & 42.00 & 10.00 \\
\hline \multirow[t]{3}{*}{ G } & $\mathrm{PN}$ & 3.67 & 1.92 & 3.50 & 1.80 & 3.36 & 1.82 \\
\hline & DIM & 131.08 & 77.31 & 126.27 & 70.72 & 129.43 & 81.01 \\
\hline & MY (kg/d) & 32.67 & 6.68 & 39.07 & 9.17 & 40.99 & 7.24 \\
\hline
\end{tabular}

Table 1. Parity number (PN), DIM, and milk yield (MY) of the cows kept in farms involved in this study 
distilled water and homogenized for 2 min at maximum speed $(260 \mathrm{rpm})$ in a Stomacher (Seward Stomacher 400 Circulator, International PBI, Milano). The homogenate aliquots were stored at $-20^{\circ} \mathrm{C}$ until analysis. The VFA were analyzed by GC using the method described by Minuti et al. (2014).

DNA Extraction from Fecal and Silage Samples. Before DNA isolation, $10 \mathrm{~g}$ of fecal or TMR samples were added to $90 \mathrm{~mL}$ of physiological solution and homogenized, 2 min at maximum speed (260 rpm), in a Stomacher (Seward Stomacher 400 Circulator, International PBI, Milano, Italy) using filter bags (Interscience, Saint Nom, France). From each homogenate, $1.5 \mathrm{~mL}$ was centrifuged at $14,000 \times g$ for $5 \mathrm{~min}$ at $4^{\circ} \mathrm{C}$, the supernatant was removed, and the pellet was used for DNA extraction. Total genomic DNA from feces was isolated by using the Stool DNA Isolation Kit (Norgen, Biotek Corporation, Thorold, ON, Canada) according to manufacturer's instructions. Briefly, the pellets isolated from each sample were first suspended in $800 \mu \mathrm{L}$ of Lysis Buffer L and added to a Norgen bead tube (catalog no. 26550) along with $100 \mu \mathrm{L}$ of Lysis Additive A to lyse Cl. tyrobutyricum spores. Samples were vortexed briefly and then homogenized in a bead beater equipment (Mini-BeadBeater 24-Cell Distruptor, BioSpec Products Inc., Bartlesville, OK) 4 times $\times$ 1 min at 2.0 oscillations/min $(\times 1,000)$. After mechanical breakage, the samples were centrifuged for $2 \mathrm{~min}$ at $14,000 \times g$ at $4^{\circ} \mathrm{C}$, to remove the beads and cellular debris, and $600 \mu \mathrm{L}$ of supernatant was transferred to a new 2-mL DNase-free microcentrifuge tube with 100 $\mu \mathrm{L}$ of binding buffer. Samples were incubated on ice for $10 \mathrm{~min}$. The lysates were then spun for $2 \mathrm{~min}$ to pellet any cell debris and supernatants were transferred to a new 2.0-mL tube with equal volume of $70 \%$ ethanol. Samples were vortexed and then transferred to a spin column, to further purify the DNA, and centrifuged for 1 min at a speed of $\geq 3,500 \times g$ at room temperature. The lysate mixture was then bound, washed, and eluted according to the manufacturer's instructions. Samples were eluted in $100 \mu \mathrm{L}$ of elution solution.

Total genomic DNA from silage was isolated by using the FastPrep DNA SpinKit for Soil (MP Biomedicals, Solon, OH) according to the manufacturer's instructions as described by Bassi et al. (2013).

The purified DNA from fecal and silage samples were analyzed by electrophoresis on 1\% agarose gel and visualized by ethidium bromide staining. A PicoGreen dsDNA Assay (Invitrogen, Eugene, OR) was used to quantify the DNA following purification. Finally, the genomic DNA was stored at $-20^{\circ} \mathrm{C}$ until use.

Real-Time PCR Analysis. Purified DNA from feces and silage samples was used to detect $C l$. tyrobutyricum spores in a quantitative TaqMan real-time
(RT) PCR assay (Bassi et al., 2013), using the LightCycler instrument 2.0 (Roche Molecular Diagnostics, Mannheim, Germany).

All samples were monitored for oligonucleotide primers (pta For-5'AAGGGAAGTGCACAACATGA3'; pta Rev-5'ACTACCAGGTGCTTTTAAATTTGC3') and probe (FAM-5'GCTAAACAAATGCAACCAGA3'TAMRA) specific for the pta gene (GenBank AY572855), to amplify an amplicon size of $150 \mathrm{bp}$. Each RT-PCR product was analyzed by electrophoresis on $2.5 \%$ agarose gel and visualized by ethidium bromide staining. Five microliters of purified dsDNA from each sample was used in the RT-PCR reaction, along with $4 \mu \mathrm{L}$ of Master mix (LightCycler TaqMan Master, Roche Diagnostics S.p.A., Monza, Italy), $1 \mu \mathrm{L}$ of each primer, $0.2 \mu \mathrm{L}$ of specific pta probe, and $8.8 \mu \mathrm{L}$ of water, for a total volume of $20 \mu \mathrm{L}$. The RT-PCR reactions were placed into the real-time thermocycler (LightCycler, Roche Diagnostics S.p.A., Monza, Italy) and were subjected to the following reaction parameters: initial template denaturation at $95^{\circ} \mathrm{C}$ for $10 \mathrm{~min}$, followed by 55 cycles of denaturation at $95^{\circ} \mathrm{C}$ for $10 \mathrm{~s}$, followed by primer annealing and extension at $59^{\circ} \mathrm{C}$ for $40 \mathrm{~s}$ and $72^{\circ} \mathrm{C}$ for $1 \mathrm{~s}$. All samples were analyzed in duplicates. In each reaction, negative and positive controls were included. The RT-PCR product of $150 \mathrm{bp}$ was analyzed by electrophoresis on $2.5 \%$ agarose gel and visualized by ethidium bromide staining. To determine the $\mathrm{Cl}$. tyrobutyricum isolated from each spiked fecal and silage sample, a duplicate set of 10 -fold dilutions was performed using an aliquot of genomic DNA from the reference $\mathrm{Cl}$. tyrobutyricum UC9038 strain (isolated from a milk sample by the Università Cattolica del Sacro Cuore, Piacenza-Cremona, Italy) containing 2.4 $\times 10^{9}$ genome equivalent $(\mathbf{G E}) / \mathrm{mL}$. Using the TaqMan assay described above, cycle threshold $(\mathbf{C t})$ values were generated from all dilutions and were used in preparing the standard curve for the real-time PCR reaction. Sample Ct were then used as $\mathrm{X}$ in the equation of the line to determine the average GE of fecal and silage samples isolated.

\section{Statistical Analysis}

All statistical analyses were performed using the statistical software package SAS 9.2 (SAS Institute Inc., Cary, NC). Data were tested for normality by the Shapiro-Wilk test. In case of nonnormality, data were normalized by log or exponential transformation. The data were analyzed with ANOVA using a mixed model (MIXED procedure of SAS). The model included the fixed effect of season (winter, spring, and summer), herd ( 7 levels), and the interaction season $\times$ herd. The analysis was carried out using 3 covariance structures: 
Table 2. TMR composition, chemical characteristics, and content of Clostidium tyrobutyricum spores ${ }^{1}$



\footnotetext{
${ }^{1}$ The minimum and maximum value observed at herd level in each season are in parentheses.

${ }^{2}$ The concentrate included the high-moisture ear corn silage, already included in the silage ingredients.

${ }^{3} \mathrm{NFC}$ calculated using $100-(\mathrm{CP}+$ ether extract + NDF - NDFIP + ash $)$, where NDFIP is the insoluble protein in NDF.

${ }^{4} \mathrm{GE}=$ genome equivalent.
}

autoregressive order, compound symmetry, and spatial power structure. These were ranked according to their Akaike and Schwarz Bayesian information criterion, with the one having the least information criterion being eventually chosen. For each treatment, least squares means were computed, and pairwise comparisons (PDIFF option of SAS) were conducted when the $F$-test of one of the season factors was significant at $P$ $<0.10$. Statistical significance was declared at $P \leq 0.05$ and a trend at $P>0.05$ to $P \leq 0.10$.

Pearson correlations among blood and fecal variables were calculated using the CORR procedure of SAS. Blood variables were processed by principal components analysis of SAS. Furthermore, Pearson correlations among principal components and fecal variables were calculated using the CORR procedure of SAS.

\section{RESULTS}

The changes of THI observed during the trial are shown in Supplemental Figure S2 (https://doi.org/10 .3168/jds.2017-13693). Climatic conditions were not different between the 3 areas where the farms were located. The daily mean THI was $40.7 \pm 4.6$ (range 25 to 55) during the winter (December to January), and 61.2 \pm 3.7 (range from 39 to 77) during the spring (April to May). During the summer (July) daily mean THI was $70.8 \pm 3.2$ (range from 54 to 83 ), daily maximum THI was $76.8 \pm 3.1$ (range 70 to 83 ), and daily minimum THI was $62.7 \pm 3.5$ (range 54 to 70 ).
The data referring to the diet characteristics (Table 2 ) consist of the overall average of the diets fed in the 3 seasons. All TMR were based on corn silage. The content of corn silage in the diets ranged from 21.6 (farm G) to $39.6 \%$ (farm D) on a DM basis (Supplemental Table S1; https://doi.org/10.3168/jds.2017-13693). The content of $\mathrm{Cl}$. tyrobutyrycum spores in the TMR did not differ between seasons.

All blood parameters were within the reference values for lactating dairy cows. A significant effect of farm has been observed for almost all the parameters controlled, with the exception of glucose, K, Zn, $\gamma$-glutamyl transpeptidase, and AP (Supplemental Table S2; https:// doi.org/10.3168/jds.2017-13693). The effect of seasons on blood parameters is reported in Table 3. Most blood parameters, except for inorganic $\mathrm{P}, \mathrm{K}$, and haptoglobin, were significantly affected by season. The concentrations of glucose, urea, $\mathrm{Mg}, \mathrm{Zn}$, and AP were lower $(P<$ $0.05)$ in summer compared with winter and spring. The concentrations of cholesterol, $\mathrm{Ca}, \mathrm{Cl}$, and albumin were lower $(P<0.05)$ in summer compared with winter. The concentrations of total bilirubin and $\mathrm{Na}$ were greater $(P$ $<0.01)$ in summer compared with winter and spring. Ceruloplasmin was greater $(P<0.01)$ in summer compared with the winter season.

The main results from the principal components analysis on blood variables have shown that principal component (PC) 1, PC2, PC3, and PC4 components explained the $19.7,10.1,9.2$, and $8.5 \%$ of the total variance, respectively. Figure 1a shows the loading plot of 
PC1 versus PC4. Albumin, cholesterol, PCV, urea, Zn, and $\mathrm{Mg}$ have positive loadings on $\mathrm{PC} 1$, whereas total proteins, globulin, and ceruloplasmin have negative loadings on the same component. The increase of PC4 was associated with greater cholesterol, $\mathrm{Ca}, \mathrm{AP}$, and glucose and with lower levels of the other blood minerals, and molar proportion of fecal butyric acid $(\mathbf{C 4} ; \mathrm{r}=$ $-0.30 ; P<0.001)$.

The PC1 separated the blood samples collected in winter from those collected in summer (Figure 1b). Plotting PC4 against PC1, the winter season was scored in the first quarter, the summer in the opposite side (third quarter), and the spring season was in fourth quarter (Figure 1b).

Supplemental Table S3 (https://doi.org/10.3168/ jds.2017-13693) shows feces characteristics of cows in the different farms. Values represent the means of the data observed in the 3 seasons. A significant effect of farm was observed for all parameters. The $\mathrm{pH}$ of the feces was generally low in all farms. A high level of variability among farms was observed for total VFA. Among VFA, acetic acid (C2), and C4 showed a great variability between farms.

Feces characteristics throughout the seasons are reported in Table 4. Fecal DM did not differ between seasons and no interaction of season $\times$ farm was observed. The values of $\mathrm{pH}$ were not affected by season and the interaction season $\times$ farm was significant. Total VFA concentrations progressively decreased from winter to summer, and summer levels were lower $(P<0.01)$ compared with winter levels. For total VFA, the season $\times$ farm interaction was significant (Table 4) and 5 out of 7 farms exhibited lower $(P<0.05)$ total VFA values in summer compared with the other seasons. The seasonal changes of $\mathrm{C} 2$ and propionic acid (C3) concentrations follow the same trend of total VFA. The C4 did not show any difference between seasons, and the season $\times$ farm interaction was significant (Table 4). Considering the molar proportion of each VFA, C2 showed lower $(P$ $<0.01$ ) values in spring compared with summer, and no difference was observed between winter and summer. The molar ratio of $\mathrm{C} 3$ was not affected by season. The $\mathrm{C} 4$ molar ratio was the greatest in summer and differed $(P<0.01)$ when compared with winter.

Fecal $\mathrm{pH}$ was negatively related $(\mathrm{r}=-0.40$ to -0.48 ; $P<0.001)$ to fecal concentration of each VFA (C2, C3, and C4) and with total VFA $(\mathrm{r}=-0.34 ; P<0.001)$. Among the relationships between fecal $\mathrm{pH}$ and VFA molar proportions, a negative correlation $(\mathrm{r}-0.31 ; P$ $<0.001$ ) was observed only with $\mathrm{C} 4$. The GE per gram of DM of $C l$. tyrobutyricum in the feces was greater $(P$ $<0.001$ ) in summer compared with spring and winter seasons (Figure 2). No difference was observed between winter and spring (Figure 2).

Table 3. Blood variables observed in lactating dairy cows in different seasons during the trial

\begin{tabular}{|c|c|c|c|c|c|c|}
\hline \multirow[b]{2}{*}{ Item $^{1}$} & \multicolumn{3}{|c|}{ Season } & \multirow[b]{2}{*}{$\mathrm{SEM}^{2}$} & \multicolumn{2}{|c|}{$P$-value ${ }^{3}$} \\
\hline & Winter & Spring & Summer & & $\mathrm{S}$ & $\mathrm{S} \times \mathrm{H}$ \\
\hline $\mathrm{PCV}(\mathrm{L} / \mathrm{L})$ & $0.316^{* *}$ & $0.306^{*}$ & 0.298 & 0.0025 & $<0.0001$ & NS \\
\hline Glucose $(\mathrm{mmol} / \mathrm{L})$ & $4.33^{* *}$ & $4.09^{*}$ & 3.99 & 0.0258 & $<0.0001$ & $<0.0001$ \\
\hline Total cholesterol $(\mathrm{mmol} / \mathrm{L})$ & $5.99 *$ & 5.65 & 5.46 & 0.1247 & 0.0106 & NS \\
\hline Urea $(\mathrm{mmol} / \mathrm{L})$ & $5.22^{* *}$ & $5.03^{* *}$ & 4.39 & 0.0857 & $<0.0001$ & $<0.0001$ \\
\hline $\mathrm{Ca}(\mathrm{mmol} / \mathrm{L})$ & $2.60^{* *}$ & $2.48^{*}$ & 2.53 & 0.0130 & $<0.0001$ & 0.0015 \\
\hline Inorganic $\mathrm{P}(\mathrm{mmol} / \mathrm{L})$ & 1.88 & 1.81 & 1.86 & 0.0309 & NS & 0.0001 \\
\hline $\mathrm{Mg}(\mathrm{mmol} / \mathrm{L})$ & $1.06^{* *}$ & $1.04^{* *}$ & 0.98 & 0.0096 & $<0.0001$ & 0.0105 \\
\hline $\mathrm{Na}(\mathrm{mmol} / \mathrm{L})$ & $141.14^{* *}$ & $142.67^{* *}$ & 143.98 & 0.1750 & $<0.0001$ & $<0.0001$ \\
\hline $\mathrm{K}(\mathrm{mmol} / \mathrm{L})$ & 4.10 & 4.15 & 4.11 & 0.0365 & NS & 0.0008 \\
\hline $\mathrm{Cl}(\mathrm{mmol} / \mathrm{L})$ & $102.56^{* *}$ & 101.79 & 101.40 & 0.2464 & 0.0370 & NS \\
\hline $\mathrm{Zn}(\mu \mathrm{mol} / \mathrm{L})$ & $12.29^{*}$ & $13.13^{* *}$ & 11.59 & 0.1980 & $<0.0001$ & 0.0228 \\
\hline Ceruloplasmin $(\mu \mathrm{mol} / \mathrm{L})$ & $3.38^{* *}$ & 3.71 & 3.89 & 0.0745 & $<0.0001$ & 0.0049 \\
\hline Total protein $(\mathrm{g} / \mathrm{L})$ & 83.39 & 82.70 & 83.63 & 0.5457 & NS & 0.0098 \\
\hline Albumin $(\mathrm{g} / \mathrm{L})$ & $36.71^{* *}$ & 35.99 & 35.63 & 0.2262 & 0.0029 & NS \\
\hline Globulin $(\mathrm{g} / \mathrm{L})$ & 46.68 & 46.71 & 48.00 & 0.6831 & NS & 0.0171 \\
\hline $\operatorname{AST}(\mathrm{U} / \mathrm{L})$ & 101.92 & $94.45^{* *}$ & 105.81 & 3.0368 & 0.0043 & NS \\
\hline GGT (U/L) & $33.36^{*}$ & 31.68 & 29.22 & 1.0526 & 0.0073 & NS \\
\hline $\mathrm{AP}(\mathrm{U} / \mathrm{L})$ & $56.83^{* *}$ & $51.67^{*}$ & 46.09 & 1.5743 & 0.0029 & NS \\
\hline Total bilirubin $(\mu \mathrm{mol} / \mathrm{L})$ & $1.16^{* *}$ & $1.03^{* *}$ & 1.48 & 0.0578 & $<0.0001$ & NS \\
\hline Haptoglobin $(\mathrm{g} / \mathrm{L})$ & 0.18 & 0.12 & 0.15 & 0.1048 & 0.0169 & NS \\
\hline
\end{tabular}




\section{DISCUSSION}

During the summer, mean daily THI maximum was around 76.8 , greater than the upper critical value $(72)$ suggested by Armstrong (1994). Overall values and changes of THI during summer season would suggest a condition of mild heat stress for lactating dairy cows (Armstrong, 1994). However, the changes of glucose,



b)

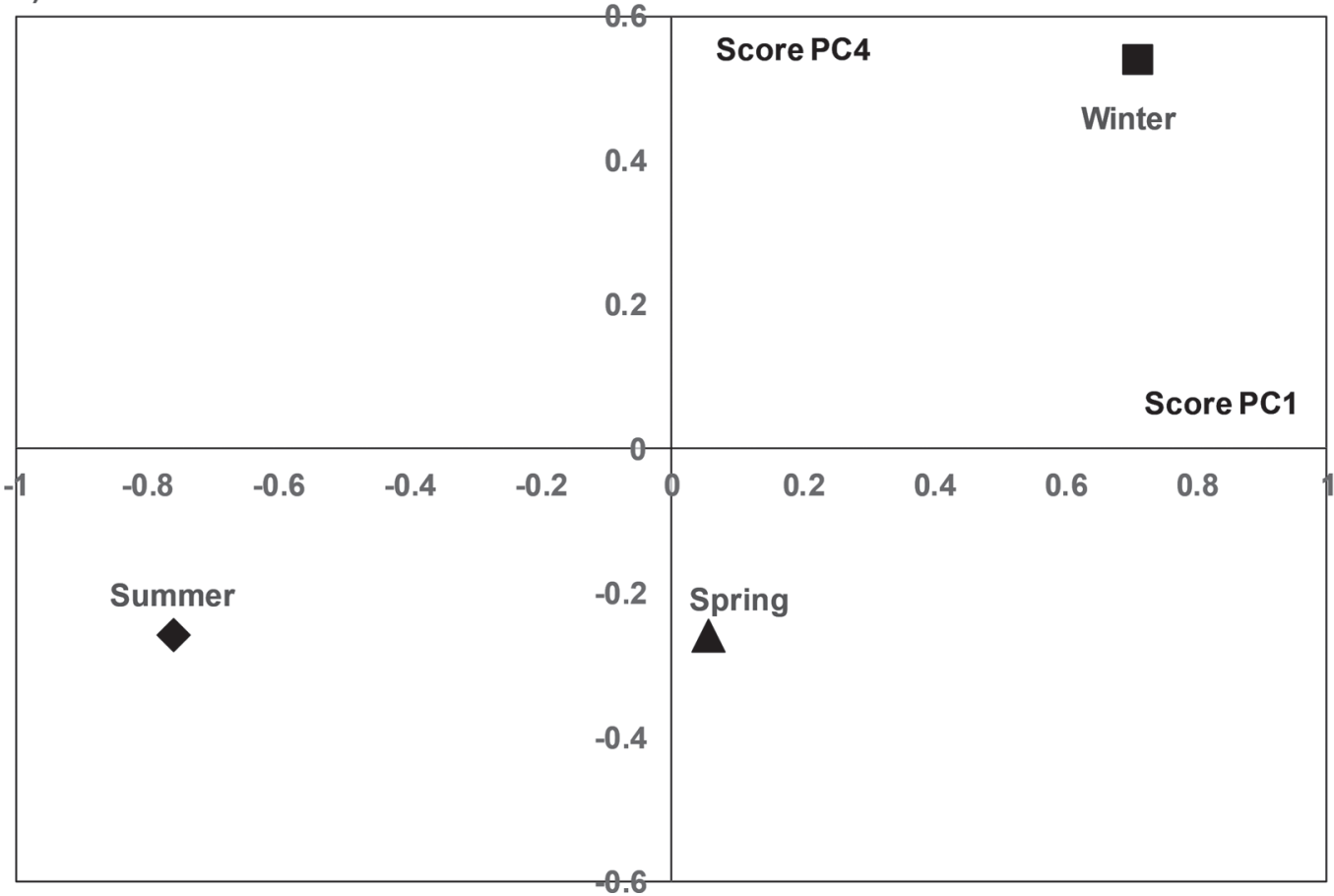

Figure 1. (a) Loading plot of principal component (PC) 1 and PC4. AP = alkaline phosphatase; AST = aspartate aminotransferase; GGT $=\gamma$-glutamyl transferase; PCV $=$ packed cell volume. (b) Score plot of PC-analyzed samples collected through the seasons using PC1 and PC4. The PC1 and PC4 accounted for $28.2 \%$ of the observed variation in the data. 
CALAMARI ET AL.

Table 4. Fecal dry matter, pH, and VFA observed in lactating dairy cows in different seasons during the trial

\begin{tabular}{|c|c|c|c|c|c|c|}
\hline \multirow[b]{2}{*}{ Item $^{1}$} & \multicolumn{3}{|c|}{ Season } & \multirow[b]{2}{*}{$\mathrm{SEM}^{2}$} & \multicolumn{2}{|c|}{$P$-value ${ }^{3}$} \\
\hline & Winter & Spring & Summer & & $\mathrm{S}$ & $\mathrm{S} \times \mathrm{H}$ \\
\hline$\overline{\mathrm{DM}}(\%)$ & 13.82 & 13.90 & 14.07 & 0.14927 & NS & NS \\
\hline $\mathrm{pH}$ & 6.03 & 6.06 & 6.07 & 0.01927 & NS & $<0.0001$ \\
\hline VFA $(\mathrm{mmol} / \mathrm{kg}$ of $\mathrm{DM})$ & $690.93^{* *}$ & 643.84 & 617.20 & 12.73509 & 0.005 & $<0.0001$ \\
\hline \multicolumn{7}{|l|}{$\mathrm{C} 2$} \\
\hline $\mathrm{mmol} / \mathrm{kg}$ of $\mathrm{DM}$ & $507.73^{* *}$ & 468.66 & 448.96 & 9.27119 & $<0.0001$ & $<0.0001$ \\
\hline $\mathrm{mol} \%$ & 73.49 & $66.40^{* *}$ & 72.93 & 0.71063 & $<0.0001$ & $<0.0001$ \\
\hline \multicolumn{7}{|l|}{$\mathrm{C} 3$} \\
\hline $\mathrm{mmol} / \mathrm{kg}$ of $\mathrm{DM}$ & $107.19^{* *}$ & 99.32 & 94.50 & 2.09265 & $<0.005$ & $<0.0001$ \\
\hline $\mathrm{mol} \%$ & 15.54 & 15.45 & 15.30 & 0.13397 & $\mathrm{NS}$ & NS \\
\hline \multicolumn{7}{|l|}{$\mathrm{C} 4$} \\
\hline $\mathrm{mmol} / \mathrm{kg}$ of $\mathrm{DM}$ & 60.23 & 62.23 & 59.83 & 1.88265 & NS & $<0.0001$ \\
\hline $\mathrm{mol} \%$ & $8.75^{* *}$ & 9.51 & 9.68 & 0.18751 & 0.005 & 0.0012 \\
\hline
\end{tabular}

${ }^{1} \mathrm{C} 2=$ acetic acid; $\mathrm{C} 3=$ propionic acid; $\mathrm{C} 4=$ butyric acid.

${ }^{2} \mathrm{SEM}=$ highest SEM.

${ }^{3} \mathrm{~S}=$ seasonal effect; $\mathrm{H}=$ herd effect.

${ }^{* *} P<0.01$ : significant differences from the value observed in summer season.

total cholesterol, and AP (Abeni et al., 2007) show that in this study the cows suffered mild to severe heat stress during summer.

The markers of inflammatory status were affected by season, indicating a greater risk of inflammation in cows during the summer. In particular, during this season there was an increase of positive acute-phase proteins (ceruloplasmin), and a decrease of negative acute-phase proteins (albumin) and total cholesterol, this latter assumed as an index of lipoproteins. Heat stress can cause an increase of gastrointestinal permeability, favoring absorption of luminal endotoxins and also bacterial translocation (Hall et al., 2001; Lambert, 2009), both factors triggering metabolic, inflammatory,

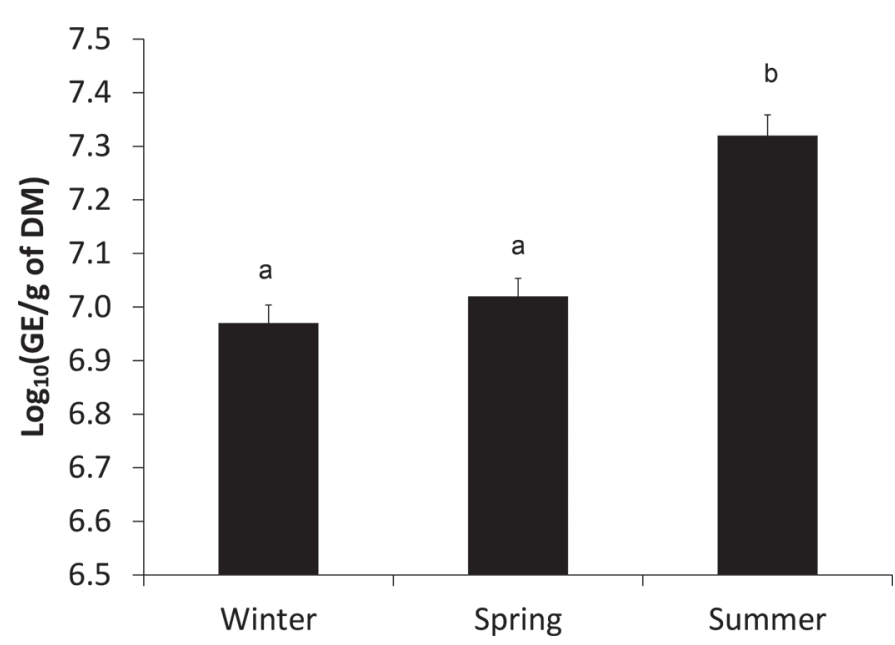

Figure 2. Least squares means and SE of Clostridium tyrobutyricum spores in feces by lactating dairy cows in different seasons. (a,b: $P<0.05) . \mathrm{GE}=$ genome equivalent. and immunological alterations (Zebeli et al., 2011; Minuti et al., 2013, 2014). The results obtained with the $\mathrm{PC}$ analysis have shown that plotting $\mathrm{PC} 1$ and $\mathrm{PC} 4$, the summer and winter seasons were confined in opposite quarter-planes. The discrimination of summer was mainly related to the blood acute phase proteins (increase of positive acute phase proteins and decrease of negative acute phase proteins), together with blood markers of energy metabolism and enzyme activities (i.e., AP).

Total VFA concentration in feces progressively decreased from winter to summer, and summer levels were significantly lower compared with winter levels. The level of total VFA concentration in feces is affected by production of VFA in the hindgut and rate of their further absorption. In turn, the production of VFA is related to the amount of carbohydrates (starch and fiber) entering the hindgut (Gressley et al., 2011). The hindgut accounts for an average of $5.4 \%$ (from 0.4 to $11.7 \%$ ) of total-tract starch and for an average of $5 \%$ (from 0.5 to $16.1 \%$ ) of total-tract NDF disappearance in lactating cows (Gressley et al., 2011). This variability is linked to factors affecting rumen degradability and intestinal digestibility (Harmon et al., 2004). Among environmental factors, heat stress is recognized to have strong effects on modifying gastrointestinal functions (Bernabucci et al., 1999, 2009; Kadzere et al., 2002).

The exposure of ruminants to hot conditions is responsible for the reduction in rumen and gut motility either as contraction amplitude or frequency (Bernabucci et al., 2009). The reduction in rumen and gut motility is responsible for the prolonged retention for feed and water in the gastrointestinal tract (Bernabucci et al., 2009) and then for the increased nutrient and water absorption (Khelil-Arfa et al., 2014). Diet digestibility 
patterns at different thermal exposures and at different time of exposure were investigated (Bernabucci et al., 2009; Yadav et al., 2013). Bernabucci et al. (2009) demonstrated that diet digestibility was reduced by chronic exposure of ewes to heat stress conditions. Yadav et al. (2013) reported that digestibility at 25 and $30^{\circ} \mathrm{C}$ did not change, whereas digestibility increased at $35^{\circ} \mathrm{C}$ and then decreased at $40^{\circ} \mathrm{C}$ thermal exposure. In the present study, the THI levels registered during summer and data from literature allow us to hypothesize that a significant effect was likely not present of hot season on the amount of carbohydrates entering the hindgut and then on fermentation and VFA production.

The majority of VFA produced in the hindgut are passively absorbed across the intestinal epithelium (Gressley et al., 2011). In humans, less than 5\% of bacterially derived VFA appear in feces due to colonic uptake, which is responsible for the major decline in concentrations along the large bowel (Topping and Clifton, 2001). In ruminants, the hindgut was found to account for 8 to $17 \%$ of total VFA absorbed from the digestive tract (Gressley et al., 2011). Under a hot environment, dairy cows decrease DMI, increase water intake, and reduce water excretion with feces (Khelil-Arfa et al., 2014), suggesting an increase of water absorption from the gastrointestinal tract for thermoregulation. This is related to the reduction in rumen and gut motility, which is responsible for the prolonged retention of feed and water in the gastrointestinal tract (Bernabucci et al., 2009). These may allow a greater VFA absorption in subjects exposed to a hot environment and might explain the lower fecal VFA concentration observed in the present study in lactating cows during summer.

As reported before, heat stress can compromise the integrity of intestinal barrier (Lambert, 2009) and enhance the permeation of several substances. Changes of blood markers of inflammation observed in the present study can support an alteration of intestinal barrier during summer.

The values of fecal $\mathrm{pH}$ observed in the present study agree with the findings of Bani et al. (2001), and are lower than those reported in literature. Lima et al. (2016) reported a fecal $\mathrm{pH}$ value of 6.57 in samples collected at different time after feeding. Li et al. (2016) found a fecal $\mathrm{pH}$ of 6.70 in dairy cows fed diet with low starch content (15-22\% on DM basis). Li et al. (2012) observed a fecal pH of 6.45 in dairy cows subjected to a SARA challenge. Mao et al. (2012) reported fecal pH of 6.42 in dairy cows fed diets containing $70 \%$ of concentrate and fecal $\mathrm{pH}$ of 7.15 in cows fed diet containing $40 \%$ of concentrate. Besides the effect of diet characteristics, there is probably also an effect of time of fecal sampling in relation to the meals and time budget behaviors.
To date, the effects of the seasons on fecal $\mathrm{pH}$ were not investigated. In the present study, the seasons did not affect fecal $\mathrm{pH}$, despite fecal total VFA were lower in summer compared with the winter season. This inconsistency suggests a difference in hindgut buffering capacity and may make the hindgut less capable of maintaining digesta $\mathrm{pH}$ during times of increased VFA production in the summer season.

The correlations between principal components and fecal characteristics showed a relationship between molar proportion of fecal $\mathrm{C} 4$ and blood minerals associated with PC4. This suggests that changes of mineral and water metabolisms and acid-base balance (Kadzere et al., 2002; Calamari et al., 2007) may be linked with changes in hindgut fermentation processes.

In the present study, a greater content of $\mathrm{Cl}$. tyrobutyricum spores in feces was observed during summer. Bani et al. (1991) observed an increase of Cl. tyrobutyricum spores in feces under hotter conditions in cows fed diet based on corn silage. Spores in feces colonize skin and hair of animals and can contaminate raw milk at milking time, increasing the risk of late blowing in cheese. Late blowing occurs in long-ripened hard and semi-hard cheeses and is mainly caused by Cl. tyrobutyricum (Le Bourhis et al., 2005; Lopez-Enriquez et al., 2007; Doyle et al., 2015). Dasgupta and Hull (1989) reported a significant correlation between late blowing in cheese and the contamination levels of spores observed in feces and in silage, suggesting that silage is the primary source of milk contamination.

All the studies mainly focused on spores in milk and on the occurrence of cheese late blowing throughout the seasons, involving many other factors besides spore content of feeds and feces. Differences in diet composition may interfere with seasonal effect. The greater Cl. tyrobutyricum spore contamination of raw milk has been recorded in winter when cows were fed with silage, compared with summer when animals were grazing (Goudkov and Sharpe, 1965; Dasgupta and Hull, 1989). Feligini et al. (2014) reported significant seasonal variations in the community of the Clostridium spp. isolated from raw milk and curd used for Grana Padano cheese, with the greatest values for $\mathrm{Cl}$. tyrobutyricum measured in spring. The highest incidence of cheeses with lateblowing defect seems to occur in spring and autumn when the temperatures are mild and humidity is high (Dasgupta and Hull, 1989). Pugh (2002) reported that fresh and humid periods, such as late winter and spring, are characterized by a greater environmental presence of Clostridia. Dasgupta and Hull (1989) observed that in the cheese factories the greatest incidence of late blowing occurs in cheeses produced in spring and autumn seasons. In Manchego cheese, the highest incidence of late-blowing defect was recorded for cheeses produced 
in summer, coinciding with the highest occurrence of Cl. tyrobutyricum spores in milk (Garde et al., 2011). All these results are affected, besides differences in spore content of feeds and feces, by many other factors that could affect milk contamination at milking throughout the seasons.

In the present study, during summer a greater content of $\mathrm{Cl}$. tyrobutyricum spores in feces was observed, despite no differences being detected in feed contamination between seasons. Current thinking is that spores ingested are unaffected by the passage throughout the intestinal tract. Digestion processes contribute to concentrate the number of spores, which could be quite higher in feces. The enteric environment does not seem to provide adequate conditions for the germination of spores of $\mathrm{Cl}$. tyrobutyricum (Drouin and Lafrenière, 2012). Nevertheless, our results seem to indicate an increase of the excreted/ingested spore ratio in cows during summer, suggesting favorable conditions of spores germination, bacterial proliferation, and new sporulation into the digestive tract of cows during summer. The hypothesis of a greater activity of Clostridia into the digestive tract is in agreement with the higher molar proportion of butyric acid in feces in summer observed in the present study. Spores germination, bacteria multiplication, and new sporulation in the digestive tract of lactating dairy cows were already hypothesized by Bani et al. (2001). Sato and Tanaka (1997) observed that the administered $\mathrm{Cl}$. butyricum spores germinated in the upper small intestine, and grew mainly from the distal small intestine to the colon in rats. Shen (2015) studied the factors affecting $\mathrm{Cl}$. difficile spore formation and germination in intestinal tract in humans. The key point that may affect the activity of Clostridium spp. seems to be represented by those factors that can influence spore germination.

\section{CONCLUSIONS}

The present study provides first evidences on the effects of hot season on fecal fermentative parameters and on the relationship between metabolic status and fecal fermentative parameters in lactating dairy cows. Results of the present study demonstrate that summer season, through direct and indirect effect of heat stress, affected fecal fermentative parameters and hindgut buffering capacity and was partially responsible for an increased occurrence of $\mathrm{Cl}$. tyrobutyricum spores in feces. The greater presence of $\mathrm{Cl}$. tyrobutyricum spores in feces of cows observed during the summer and the lack of differences for the spores concentration in the diet between the seasons, indicate an increase of excreted/ ingested spore ratio in cows during summer. Data from the present study did not allow a definitive conclusion on the main factors involved in the germination process in heat-stressed cows, but they suggest the interest to study in depth the relationships between the modifications induced by heat stress on animal metabolism, gut environment, and $\mathrm{Cl}$. tyrobutyricum spores multiplication.

\section{ACKNOWLEDGMENTS}

This project was financially supported by the Ministero delle Politiche Agricole, Alimentari e Forestali, Roma, Italy (MiPAAF)-FILIGRANA project (D.M. 25741/7303/11-01/12/2011). The authors thank Angelo Stroppa (Grana Padano Consortium, Desenzano del Garda, BS, Italy) and the farmers where the study was carried out.

\section{REFERENCES}

Abeni, F., L. Calamari, and L. Stefanini. 2007. Metabolic conditions of lactating Friesian cows during hot season in Po valley. 1. Blood indicators of heat stress. Int. J. Biometeorol. 52:87-96.

AOAC. 1990. Official Methods of Analysis, 15th ed. Association of Official Analytical Chemists, Washington, DC.

Armstrong, D. V. 1994. Heat stress interaction with shade and cooling. J. Dairy Sci. 77:2044-2050.

Bani, P., G. Bertoni, P. Gilardelli, and R. Gennari. 1991. Prime ricerche su alcuni fattori di variazione del contenuto di spore di Clostridium nelle feci di lattifere. Sci. Tecn. Latt-Cas. 42:29-46.

Bani, P., L. Calamari, E. Bettinelli, and G. Bertoni. 2001. [Composizione della razione e contenuto in spore di clostridi nelle feci di bovine in lattazione.] Sci. Tecn. Latt-Cas. 52:369-386.

Barash, J. R., J. K. Hsia, and S. S. Arnon. 2010. Presence of soildwelling clostridia in commercial powdered infant formulas. J. Pediatr. 156:402-408.

Bassi, D., C. Fontana, S. Zucchelli, S. Gazzola, and P. S. Cocconcelli. 2013. TaqMan real time-quantitative PCR targeting the phosphotransacetylase gene for Clostridium tyrobutyricum quantification in animal feed, faeces, milk and cheese. Int. Dairy J. 33:75-82.

Baumgard, L. H., and R. P. Rhoads. 2013. Effects of heat stress on postabsorptive metabolism and energetics. Annu. Rev. Anim. Biosci. 1:311-337.

Bernabucci, U., P. Bani, B. Ronchi, N. Lacetera, and A. Nardone. 1999. Influence of short- and long-term exposure to a hot environment on rumen passage rate and diet digestibility by Friesian heifers. J. Dairy Sci. 82:967-973.

Bernabucci, U., L. Basiricò, P. Morera, D. Dipasquale, A. Vitali, F. Piccioli Cappelli, and L. Calamari. 2015. Effect of summer season on milk protein fractions in Holstein cows. J. Dairy Sci. 98:18151827

Bernabucci, U., S. Biffani, L. Buggiotti, A. Vitali, N. Lacetera, and A. Nardone. 2014. The effects of heat stress in Italian Holstein dairy cattle. J. Dairy Sci. 97:471-486.

Bernabucci, U., N. Lacetera, L. H. Baumgard, R. P. Rhoads, B. Ronchi, and A. Nardone. 2010. Metabolic and hormonal acclimation to heat stress in domesticated ruminants. Animal 4:1167-1183.

Bernabucci, U., N. Lacetera, P. P. Danieli, P. Bani, A. Nardone, and B. Ronchi. 2009. Influence of different periods of exposure to hot environment on rumen function and diet digestibility in sheep. Int. J. Biometeorol. 53:387-395.

Bertocchi, L., A. Vitali, N. Lacetera, A. Nardone, G. Varisco, and U. Bernabucci. 2014. Seasonal variations in the composition of Holstein cow's milk and temperature-humidity index relationship. Animal 8:667-674. 
Calamari, L., F. Abeni, F. Calegari, and L. Stefanini. 2007. Metabolic conditions of lactating Friesian cows during hot season in Po valley. 2. blood minerals and acid-base chemistry. Int. J. Biometeorol. 52:97-107.

Calamari, L., A. Ferrari, A. Minuti, and E. Trevisi. 2016. Assessment of the main plasma parameters included in a metabolic profile of dairy cow based on Fourier Transform mid-infrared spectroscopy: preliminary results. BMC Vet. Res. 12:4.

Das, R., L. Sailo, N. Verma, P. Bharti, J. Saikia, Imtiwati, and R. Kumar. 2016. Impact of heat stress on health and performance of dairy animals: A review. Vet. World 9:260-268.

Dasgupta, A. P., and R. R. Hull. 1989. Late blowing of Swiss cheese: incidence of Clostridium tyrobutyricum in manufacturing milk. Aust. J. Dairy Technol. 44:82-87.

Doyle, C. J., D. Gleeson, K. Jordan, T. P. Beresford, R. P. Ross, G. F. Fitzgerald, and P. D. Cotter. 2015. Anaerobic sporeformers and their significance with respect to milk and dairy products. Int. J. Food Microbiol. 197:77-87.

Drouin, P., and C. Lafrenière. 2012. Clostridial spores in animal feeds and milk. Pages 375-394 in Milk Production-An Up-to-Date Overview of Animal Nutrition, Management and Health. N. Chaiyabutr, ed. Intech, UK.

ESRI. 2015. ArcGIS Desktop Release 10.3.1. Environmental Systems Research Institute, Redlands, CA.

European Union. 2010. EU Directive 2010/63/EU of 22 September 2010 on the protection of animals used for scientific purposes. Off. J. Eur. Commun. L276:33-79.

Feligini, M., E. Brambati, S. Panelli, M. Ghitti, R. Sacchi, E. Capelli, and C. Bonacina. 2014. One-year investigation of Clostridium spp. occurrence in raw milk and curd of Grana Padano cheese by the automated ribosomal intergenic spacer analysis. Food Control 42:71-77.

Garde, S., R. Arias, P. Gaya, and M. Nuñez. 2011. Occurrence of Clostridium spp. in ovine milk and Manchego cheese with late blowing defect: Identification and characterization of isolates. Int. Dairy J. $21: 272-278$.

Goudkov, A. V., and M. E. Sharpe. 1965. Clostridia in dairying. J. Appl. Bacteriol. 28:63-73.

Gressley, T. F., M. B. Hall, and L. E. Armentano. 2011. Productivity, digestion, and health responses to hindgut acidosis in ruminants. J. Anim. Sci. 89:1120-1130.

Hall, D. M., G. R. Buettner, L. W. Oberley, L. Xu, R. D. Matthes, and C. V. Gisolfi. 2001. Mechanisms of circulatory and intestinal barrier dysfunction during whole body hyperthermia. Am. J. Physiol. Heart Circ. Physiol. 280:H509-H521.

Hansen, P. J. 2009. Effect of heat stress on mammalian reproduction. Philos. Trans. R. Soc. Lond. B Biol. Sci. 364:3341-3350.

Harmon, D. L., R. M. Yamka, and N. A. Elam. 2004. Factors affecting intestinal starch digestion in ruminants: A review. Can. J. Anim. Sci. 84:309-318.

Ingraham, R. H., R. W. Stanley, and W. C. Wagner. 1979. Seasonal effects of tropical climate on shaded and non-shaded cows as measured by rectal temperature, adrenal cortex hormones, thyroid hormone, and milk production. Am. J. Vet. Res. 40:1792-1797.

Kadzere, C. T., M. R. Murphy, N. Silanikove, and E. Maltz. 2002. Heat stress in lactating dairy cows: A review. Livest. Prod. Sci. 77:59-91.

Khelil-Arfa, H., P. Faverdin, and A. Boudon. 2014. Effect of ambient temperature and sodium bicarbonate supplementation on water and electrolyte balances in dry and lactating Holstein cows. J. Dairy Sci. 97:2305-2318.

Lacetera, N., U. Bernabucci, D. Scalia, B. Ronchi, G. Kuzminsky, and A. Nardone. 2005. Lymphocyte functions in dairy cows in hot environment. Int. J. Biometeorol. 50:105-110.

Lambert, G. P. 2009. Stress-induced gastrointestinal barrier dysfunction and its inflammatory effects. J. Anim. Sci. 87:E101-E108.
Le Bourhis, A. G., K. Saunier, J. Dore, J. P. Carlier, J. F. Chamba, and M. R. Popoff. 2005. Development and validation of PCR primers to assess the diversity of Clostridium spp. in cheese by temporal temperature gradient gel electrophoresis. Appl. Environ. Microbiol. 71:29-38.

Ledenbach, L. H., and R. T. Marshall. 2010. Microbiological spoilage of dairy products. Pages 41-67 in Compendium of the Microbiological Spoilage of Foods and Beverages. W. H. Sperber and M. P. Doyle, ed. Springer, New York, NY.

Li, S., I. Yoon, M. Scott, E. Khafipour, and J. C. Plaizier. 2016. Impact of Saccharomyces cerevisiae fermentation product and subacute ruminal acidosis on production, inflammation, and fermentation in the rumen and hindgut of dairy cows. Anim. Feed Sci. Technol. 211:50-60.

Li, S., E. Khafipour, D. O. Krause, A. Kroeker, J. C. RodriguezLecompte, G. N. Gozho, and J. C. Plaizier. 2012. Effects of subacute ruminal acidosis challenges on fermentation and endotoxins in the rumen and hindgut of dairy cows. J. Dairy Sci. 95:294-303.

Lima, S., M. F. Palin, G. T. Santos, C. Benchaar, and H. V. Petit. 2016. Dietary flax meal and abomasal infusion of flax oil on microbial $\beta$-glucuronidase activity and concentration of enterolactone in ruminal fluid, plasma, urine and milk of dairy cows. Anim. Feed Sci. Technol. 215:85-91.

Lopez-Enriquez, L., D. Rodriguez-Lazaro, and M. Hernandez. 2007. Quantitative detection of Clostridium tyrobutyricum in milk by real-time PCR. Appl. Environ. Microbiol. 73:3747-3751.

Mao, S., R. Zhang, D. Wang, and W. Zhu. 2012. The diversity of the fecal bacterial community and its relationship with the concentration of volatile fatty acids in the feces during subacute rumen acidosis in dairy cows. BMC Vet. Res. 8:237.

Mertens, D. R. 1997. Creating a system for meeting the fiber requirements of dairy cows. J. Dairy Sci. 80:1463-1481.

Minuti, A., S. Ahmed, E. Trevisi, F. Piccioli-Cappelli, G. Bertoni, and P. Bani. 2013. Assessment of gastrointestinal permeability by lactulose test in sheep after repeated indomethacin treatment. J. Anim. Sci. 91:5646-5653.

Minuti, A., S. Ahmed, E. Trevisi, F. Piccioli-Cappelli, G. Bertoni, N. Jahan, and P. Bani. 2014. Experimental acute rumen acidosis in sheep: Consequences on clinical, rumen, and gastrointestinal permeability conditions and blood chemistry. J. Anim. Sci. 92:3966-3977.

Nardone, A., B. Ronchi, N. Lacetera, M. S. Ranieri, and U. Bernabucci. 2010. Effect of climate changes on animal production and sustainability of livestock systems. Livest. Sci. 130:57-69.

NRC. 2001. Nutrient Requirements of Dairy Cattle. 7th rev. ed. Natl. Acad. Press, Washington, DC.

Pugh, D. G. 2002. Sheep and Goat Medicine. W. B. Saunders Co., Philadelphia, PA.

Sato, R., and M. Tanaka. 1997. Intestinal distribution and intraluminal localization of orally administered Clostridium butyricum in rats. Microbiol. Immunol. 41:665-671.

Shen, A. 2015. A gut odyssey: The impact of the microbiota on Clostridium difficile spore formation and germination. PLoS Pathog. 11:e1005157. https://doi.org/10.1371/journal.ppat.1005157.

Topping, D. L., and P. M. Clifton. 2001. Short-chain fatty acids and human colonic function: Roles of resistant starch and non-starch polysaccharides. Physiol. Rev. 81:1031-1064.

Vitali, A., A. Felici, S. Esposito, U. Bernabucci, L. Bertocchi, C. Maresca, A. Nardone, and N. Lacetera. 2015. The effect of heat waves on dairy cow mortality. J. Dairy Sci. 98:4572-4579.

Yadav, B., G. Singh, A. K. Verma, N. Dutta, and V. Sejian. 2013. Impact of heat stress on rumen functions. Vet. World 6:992-996.

Zebeli, Q., S. M. Dunn, and B. N. Ametaj. 2011. Perturbations of plasma metabolites correlated with the rise of rumen endotoxin in dairy cows fed diets rich in easily degradable carbohydrates. J. Dairy Sci. 94:2374-2382. 